\title{
Bohater, wojownik i panna: użycie archetypów i mitów w stworzeniu wizerunku ukraińskich polityków
}

\author{
Hero, Warrior and Virgin: Using Archetypes and Myths \\ for Producing the Images of the Ukrainian Politicians
}

\begin{abstract}
An important role in the process of image cultivation is played by the technologies, related to the appeal to the archaic layers of mass consciousness, in particular, to the use of archetypes. Analysis of the images of the leading Ukrainian politicians - Arseniy Yacenyuk, Yuliya Timoshenko and Vitaliy Klichko - in 2009-2014 testifies that all of them used as a basis of image-building the archetypes of Hero and Warrior in different variations, such as Hero-warrior, Cultural hero, Lady-warrior. The progress of the use of this technology depends significantly on the personal qualities of each politician, as well as on the social and the political circumstances.
\end{abstract}

Keywords: image, archetype, mythological consciousness, political leader, Ukraine Słowa kluczowe: wizerunek, archetyp, mitologiczna świadomość, polityczny lider, Ukraina

\section{Wstęp}

Kiedy Marshall McLuhan ogłosił przejście od cywilizacji słowa do cywilizacji obrazu, jeszcze mogły zachodzić wątpliwości co do znaczenia wizerunku politycznego lidera; lecz we współczesnym świecie oczywistość związku między poprawnie zbudowanym obrazem i sukcesem $\mathrm{w}$ polityce wyszła poza ramy ścisłego grona badaczy i jest znana powszechnie. Ważne miejsce w procesie budowy wizerunku zajmują mechanizmy, związane z apelowaniem do archaicznych warstw masowej świadomości. W szczególności, dotyczy to użycia przy tworzeniu pozytywnego obrazu polityka tych archetypów, które najbardziej odpowiadają współczesnym wymogom dotyczącym przedstawiciela władzy politycznej (według C.G. Junga archetyp to, wrodzone struktury świadomości, właściwe wszystkim ludziom bez względu na płeć, wiek, etniczną przynależność, poziom kultury i tym podobne. Te struktury odzwierciedlają najbardziej ogólne łączniki i stosunki otaczającego 
świata i najbardziej znaczące cechy jego organizacji. Według C.G. Junga, z archetypów, jak ze strukturalnych elementów nieświadomości zbiorowej, pochodzą archetypy obrazów (ludzi, zwierząt, sił przyrody), które dominują w myśleniu i kulturze) $)^{1}$.

Ponieważ archetypy są elementami świadomości zbiorowej całej ludzkości, wykorzystują je specjaliści od wizerunku różnych państw. Zestaw pozytywnych archetypów, które stosują w trakcie tworzenia wizerunku jest dość ograniczony. Przede wszystkim to archetypy: Twórcy i Demiurga (Boskiego Budowniczego); Bohatera; Ojca i Matki (zwłaszcza w państwach autorytarnych), Mędrca (Mądrego Starca), Króla (w monarchiach i państwach autorytarnych), Kapłana (w teokracjach), Wojownika, Panny². Pozytywny obraz polityka może być zbudowany w oparciu o połączenie kilku archetypów (a każdy archetyp może zrealizować się w kilku obrazach). Przy tym każdy z nich wciela się w obrazy, charakterystyczne dla danej kultury narodowej.

Na Ukrainie, z jej personifikacją politycznych instytucji i rozpowszechnieniem manipulacji politycznych, użycie archetypów przy tworzeniu wizerunku polityka jest bardzo popularne. W ostatnich latach pisało o tym wielu ukraińskich naukowców, w szczególności: Olena Donczenko, Larysa Koczubej, Volodymyr Polohalo, Juri Romanenko, Juri Szajgorodski i inni. Jednak wciąż istnieją zagadnienia wymagające dalszych badań.

Celem studium jest analiza użycia archetypów jako techniki budowy wizerunku czołowych ukraińskich polityków na przykładzie Arsenija Jaceniuka, Julii Tymoszenko i Witalija Kłyczki w latach 2010-2014. Wybrany okres pozwala na obserwowację ewolucji obrazu polityków i wytłumaczenie jej przyczyn.

\section{Archetypy jako technika budowy wizerunku czołowych ukraińskich polityków w latach 2010-2014}

Arsenij Jaceniuk i Julia Tymoszenko byli uczestnikami prezydenckiej kampanii w roku 2010, którą zaczęli z wyraźnie zarysowanymi wizerunkami. Wiadomo, że jednym z głównych zadań prezydenckich sztabów wyborczych jest stworzenie maksymalnie pozytywnego obrazu kandydata; może on: 1. być twórczą odmianą już istniejącego (Tymoszenko); 2. zupełnie nowy (Jaceniuk). W wyborach w 2010

1 К.Г. Юнг, Архетип и символ, Москва 1991, s. 109.

2 Аж. Кэмпбелл, Герой с тысячью личами, Sofia 1997, s. 336. 
podłożem obu kampanii było apelowanie do archaicznych warstw świadomości społecznej przez dołączenie odpowiednich archetypów³

Twórcy wizerunku Jaceniuka wykorzystali klasyczny obraz, nieraz już wykorzystywany w XX stuleciu - archetyp Bohatera. Ponieważ jest on nieodłączny od swojego mitu, warto przypomnieć jego fabułę. Prologiem mitu jest idylla, w którą „wkradają się" siły chaosu - potwory, które mordują ludzi, burzą domy. Miasto, kraj, a nawet cały wszechświat jest w niebezpieczeństwie. Wydaje się, że nadziei na ratunek nie ma - lecz oto pojawia się ktoś, zazwyczaj płci męskiej, kto decyduje się przeciwstawić siłom zła. Bohater może przegrać całe bitwy, oprócz ostatniej, w której zwycięża i dostaje nagrodę: pannę, koronę, wieczną sławę itp. Klasycznym przykładem archetypu Bohatera są mity, w których młody wojownik zwycięża smoka albo innego potwora i uwalnia przepiękną brankę.

Bliski archetypowi Bohatera jest archetyp Wojownika. Najważniejsza różnica między nimi polega na tym, że Wojownik - to fachowiec, a Bohater - wybraniec, czyli jego zwycięstwa nie zawsze kojarzą się z militarnymi zdolnościami. Oczywiście, w XXI stuleciu nikt nie wykorzystuje mitu o Bohaterze w pierwotnym przekazie. Lecz główna jego fabuła - zwycięstwo nad siłami Chaosu i naprawa (odnowa) ustroju - zostaje, transformując się odpowiednio do kulturowej i politycznej sytuacji.

W wyborach w 2010 Jaceniuk wystartował jako kandydat bezpartyjny, chociaż w 2009 utworzył ruch społeczno-polityczny Inicjatywa Obywatelska Arsenija Jaceniuka „Front Zmian”. Militarystyczna nazwa tej organizacji jest dosyć wymowna. Front kojarzy się z wojną, bitwami, sytuacją nadzwyczajną. To samo skojarzenie wywoływał wizerunek kandydata na prezydenta. Najbardziej widoczne formy jego wizualizacji stanowiła seria bilbordów z charakterystycznymi zwrotami „Kraj uratuje nowa industrializacja”, „Uratować kraj. Arsenij”, „Kraj uratują zdrowi wykształceni ludzie", itp. Bilbordy odtwarzały fabułę mitu: jeśli kraj należy ratować, to jest on w niebezpieczeństwie, a sytuacja - krytyczna; kolejnym etapem jest pojawienie sie Bohatera-wojownika - tylko on jest zdolny zwyciężyć w bitwie ze złem (Chaosem). Trzeba zauważyć, że ze względu na poziom dramatyzmu (to prawie eschatologia) bilbordy Jaceniuka są unikalne (porównajmy zwroty innych kandydatów: „Twoja myśl - ważna! Usłyszę każdego” (W. Janukowycz), „Oni obiecują. Ona pracuje” (J. Tymoszenko), „Silny prezydent - silny kraj” (S. Tihipko).

Jedną z przyczyn, która spowodowała, że twórcy wizerunku A. Jaceniuka wykorzystali archetyp Bohatera-wojownika, był kryzys gospodarczy i polityczny.

3 С. Романюха, Рекламная кампания кандидатов в Президенты Украинь, http://psyfactor. org/lib/polit5.htm, odczyt z 12.12.2009. 
W skomplikowanych społeczno-politycznych warunkach stosowane archetypu Bohatera-wojownika zazwyczaj jest efektywne. Ostateczny wariant wizerunku najmłodszego kandydata na prezydenta wyglądał następująco: młody, energiczny, silny wojownik, obrońca i wybawca, i jednocześnie - efektywny kryzysowy menadżer nowego pokolenia. Połączenie dawnego archetypu Bohatera ze współczesnym obrazem kryzysowego menadżera, według opinii jego twórców, miało gwarantować zwycięstwo w wyborach.

Oba składniki trudno połączyć ze sobą, ale może to dać pomyślne wyniki tylko na odpowiednim kulturowym polu. Genialny menadżer-wojownik, który ratuje firmę od upadku - to kultowy bohater zachodniej i japońskiej korporacyjnej kultury. Większość ludności Ukrainy nie zna i nie rozumie tego archetypu. Już w trakcie rozwoju kampanii wyborczej A. Jaceniuka zaczęły się dyskusje dotyczące jej słuszności. Istniały spory co do oceny zbudowanego wizerunku wyborczego kandydata. Część specjalistów uważała, że „Jaceniuk jest bardzo udanym wizualnie, politycznym obrazem. [...] Polityk-fantom, do pewnego stopnia, lecz efektywny fantom. Prawidłowa retoryka, wizualny obraz, 'białe' CV, czyli to właściwy wizerunek nowego menadżera, pozbawionego szorstkich ideologicznych stereotypów” ${ }^{4}$. Inni eksperci uważali, że „Ludzie nie widzą w nim fachowego menadżera”. Widoczne jest zatem, iż kreatorom wizerunku Jaceniuka nie udało się osiągnąć porozumienia.

Drugim słabym punktem była niezgodność skonstruowanego wizerunku i realnej osobowości. Biografia Jaceniuka nie zawierała żadnych elementów, które pozwoliłyby chociaż powierzchownie skojarzyć jego obraz z: „wojną”, „bitwą”, „wojownikiem”. Nie podjęto też próby sztucznego skonstruowania odpowiednich wydarzeń. Sylwetka kandydata wprost przeczyła wybranemu archetypowi. Drobne rysy twarzy, okulary, łysina są charakterystyczne dla całkiem innego archetypu - Mędrca. Pretendent na archetyp Bohatera musi odpowiadać powszechnie przyjętemu obrazowi „silnej osobistości” i „prawdziwego mężczyźny”, a Jaceniuk tym wyobrażeniom nie odpowiadał.

Te oraz inne błędy (w szczególności, nieuzasadnione nawiązanie autorów bilbordów do stylistyki lat trzydziestych XX w. i mrocznej kolorystycznej gamy) doprowadziły do porażki Jaceniuka w wyborach: zajął czwartą pozycję zdobywając poparcie $6,96 \%{ }^{6}$.

4 Ю. Абібок, На західному „Фронті” без змін?, http://zaxid.net/home/showSingleNews. do?na_zahidnomu_fronti_bez_zmin\&objectId=1084751, odczyt z 3.09.2009.

5 С. Солоньска., Н. Талалай., Політична міфологія Украӥни: імідж кандидатів, httр:// www.unian.net/ukr/news/news-345046.html, odczyt z 4.11. 2009.

6 Результати периого туру виборів Президента України 2010 в порівнянні, http://holos. com.ua/2010/01/rezultat-pershoho-turu-vyboriv-presydenta-2010/, odczyt z 28.01.2010. 
Klęska stała się lekcją dla jego marketingowców. W wyborczej kampanii 2012 roku, w której Jaceniuk brał udział jako lider listy wyborczej „Batkiwszczyny”, jego wizerunek skorygowano. $\mathrm{Z}$ bilbordów znikają mroczne kolory i militarystyczne skojarzenia; obraz staje się „ciepły”, nieformalny (rozpięty kołnierzyk koszuli). Ponieważ ta nieformalność i jasne kolory podkreślają względnie młody wiek polityka, Jaceniuk eksperymentuje z wyglądem zewnętrznym, chcąc w ten sposób uzyskać większą wiarygodność. Główny nacisk położono jednak nie na wizualnym, a na werbalnym składniku wizerunku, co jest logiczne, ponieważ Jaceniuk jest dobrym oratorem. Zauważalne jest, iż archetyp Bohatera w dalszym ciągu zostaje podstawą jego wizerunku, ujawniając się w drugiej połowie 2013 roku. Obraz silnego lidera, zdolnego zwyciężyć kryzys, podkreśla agresywna stylistyka jego wystąpień, modulacja głosu i zmiany w wyglądzie zewnętrznym (nieogolony podbródek w stylu „macho”).

Archetyp Bohatera w wizerunku Jaceniuka wykorzystano w czasie wydarzeń na Euromajdane w listopadzie 2013-lutym 2014 roku. Niewątpliwie, polityk, który stale przebywa w centrum otwartej konfrontacji między władzą i opozycją, zwłaszcza po przejściu do otwartego zbrojnego konfliktu, wywołuje odpowiednie skojarzenia nawet bez dodatkowych środków. W tym okresie charakterystycznymi cechami wizerunku Jaceniuka były agresywna retoryka, podparta odpowiednią gestykulacją (ściśnięta w pięść), ciemne kolory odzieży (charakterystyczne i dla innych liderów opozycji - Kłyczki i Tiahnyboka). Byłe: Wojownik i Menadżer zniknęli, ustąpiwszy miejsca obrazowi Bohatera-lidera, którego wyniósł lud i który prawie niczym od tego ludu się nie różni. $Z$ tego obrazu wybijały się najbardziej okulary z ich absolutnie innym symbolicznym obciążeniem.

Czy tym razem można stwierdzić, że archetyp Bohatera był przedstawiony jak należy? Według mass mediów, odbieranie Jaceniuka przez uczestników Euromajdanu było niejednoznaczne, oczywiście, nie tylko z powodu wizerunku?

Archetyp Bohatera należy do tych, których łatwość wykorzystania jest myląca. Być może, właśnie dlatego specjaliści od wizerunku drugiego lidera Euromajdanu - Witalija Kłyczki - wybrali inną drogę.

W odróżnieniu od fachowego pracownika administracji Jaceniuka, Kłyczko przyszedł do polityki z wielkiego sportu. Będąc gwiazdą o światowej skali, już miał swój obraz - wielokrotnego mistrza, triumfatora-zwycięzcy, pupila publiczności. Wcale nie ostatnie miejsce w tym wizerunku zajmowała agresywna

Кандидатуру Яиенюка на пост премьера Майдан встретил криками „Пулю в лоб”, http://www.unian.net/politics/890391-kandidaturu-yatsenyuka-na-post-premera-maydanvstretil-krikami-pulyu-v-lob.html, odczyt z 27.02.2014. 
pięściarska maniera Kłyczki, za którą dostał przydomek „Doktor Żelazna Pięśc” (Doctor Iron Fist).

Specjaliści od wizerunku mieli za zadanie: wykorzystać popularność Kłyczki, jako sportowca i skierować rzesze jego miłośników w inną sferę działalności zrobić z gwiazdy sportu gwiazdę polityki. W zasadzie, w tym zadaniu nie było nic nadzwyczajnego: we współczesnym świecie sportowiec, który zaangażował się w politykę, nie jest czymś unikatowym. Wystarczy wspomnieć George Bea, jednego z najbardziej znanych afrykańskich piłkarzy, który po zakończeniu kariery w 2005 roku kandydował na prezydenta Liberii lub słynnego piłkarza Kachu Kaladze, który został wicepremierem rządu Gruzji. W Rosji wielu byłych sportowców jest deputowanymi Państwowej Dumy (Anton Sicharulidze, Alina Kabajewa, Nikołaj Wałujew, Aleksandr Karielin i inni), a mistrz świata w szachach Garri Kasparow, swego czasu był jednym z liderów opozycji. Stosunkowo łatwe wchodzenie w politykę można wyjaśnić tym, że gwiazdy sportu są obecne w informacyjnym przekazie, ich obraz istnieje w świadomości społecznej, należy tylko przenieść ich z jednej warstwy tej świadomości do innej. Innymi słowy specjaliści od wizerunku mają możliwość częściowego użycia istniejącego wizerunku, który może występować jako fundament dla budowy nowego. Bardzo proste wydawało się będzie zbudowanie obrazu Kłyczki-polityka z Kłyczki-sportowca, położywszy nacisk na jego bojowe zdolności i siłę „Doktora Żelazna Pięść” - lecz tak się nie stało.

Nazwa partii Kłyczki - „Cios” i pąs bilbordów stanowił, faktycznie, jedyny element, przypominajacy agresję, a zarazem sportową przeszłość Kłyczki. Ani ubranie, ani stylistyka występów, ani komunikatywne zachowanie nie wywołują skojarzeń ze sportem: na wyborczych bilbordach jest on ubrany w zwyczajny garnitur lub białą koszulę, charakterystyczny sposób jego przemówień cechuje dyskrecja i mniejsza emocjonalność, niż np. u Jaceniuka. Na spotkaniach z wyborcami Kłyczko demonstrował otwartą, niewymuszoną, koleżeńską manierę obcowania z licznymi uściskami dłoni, starając się mówić z otaczającymi go ludźmi jak równy z równym. Polityk konsekwentnie kreślił obraz szczerego, otwartego człowieka, który, być może, nie posiada wybitnych oratorskich zdolności, lecz może zrozumieć innych ludzi. O tych cechach, jako podstawie wizerunku przypomina również slogan z przedwyborczych bilbordów Kłyczki: „Polityka może być szczera”. Do pewnego stopnia obraz Kłyczki był zbudowany na zasadzie kontrastu, utajonego, lecz odczuwalnego: jego osobiste cechy, w szczególności uczciwość, przyzwoitość i nieskazitelna reputacja przeciwstawiają się negatywnym cechom wielu przedstawicieli współczesnego politycznego systemu. Nie było to jednak na tyle wyraźnie, żeby można było stwierdzić, że podstawą wizerunku Kłyczki jest jedna z odmian archetypu Bohatera - bohater, który rzuca wezwanie systemowi. 
Zauważalnym jest, iż podstawą wizerunku Kłyczki jest nie Bohater-wojownik, zwycięzca potworów i smoków, jak można byłoby oczekiwać. Analiza programu partii Udar ${ }^{8}$, w którym pierwsze miejsce zajmuje budowa i wsparcie rozwoju społeczeństwa obywatelskiego, tworzenie warunków dla socjalnej odpowiedzialności biznesu, demokracja uczestnicząca i społeczny dialog, a także slogany na kształt „Gospodarka równych możliwości” pozwalają przypuszczać, iż miało miejsce użycie innego wariantu archetypu Bohatera, a mianowicie Kulturowego Bohatera, Twórcy, Budowniczego.

Najważniejszą jego misją jest twórcze przekształcenie świata ze stanu Chaosu w stan Pokoju i późniejsze jego urządzenie w sposób najlepszy dla ludzi. Taki bohater może wprowadzać prawa, uczyć. Działalność Kulturowego Bohatera nie zawsze jest absolutnym dobrem, lecz zawsze towarzyszy historycznym przemianom. Najwybitniejszym i powszechne akceptowanym bohaterem europejskiej mitologii jest Prometeusz.

Polityk, który wykorzystuje ten archetyp, pretenduje do roli Heros civilisateur, który przynosi ludziom jeśli nie ogień, to wartości demokracji. Chociaż Bohater Kulturowy jest zdolny do wielkich czynów, jest on jednak nakierowany na zgodę i współpracę a nie na konflikt.

Powstaje pytanie: dlaczego specjaliści wybrali akurat taką odmianę archetypu? Prawdopodobnie, przyczyną jest właśnie sportowy wizerunek i zewnętrzne cechy Kłyczki. Jeśli do atletycznej sylwetki, brutalnych rysów twarzy i pokaźnego wzrostu $(202 \mathrm{~cm})$ dodać agresywną retorykę i ubranie w stylu militarystycznym, może stać się to postrachem dla widowni. Jednak potencjał wybranego archetypu okazał się w wizerunku Witalija Kłyczki nie do końca wykorzystany.

W odróżnieniu od Jaceniuka i Kłyczki, Julija Tymoszenko jest doświadczonym graczem na „mitologicznym polu”, a analizie jej wizerunku są poświęcone nie tylko artykuły, ale i dysertacje. Badacze nieraz starali się wyznaczyć szereg mitologicznych obrazów, po które sięgała Tymoszenko w okresie swojej politycznej kariery. Według jednych, to „Rusałka”, „Beregynia”, Ofiara/Męczennica, znów Beregynia, Bogini (Rewolucji) ${ }^{9}$; inni uważają, że w swoim wizerunku liderka bloku politycznego wykorzystała archetyp Bohatera, wojownika-obrońcy ${ }^{10}$. Analiza

8 Програмапартї̈.Партія,,Удар”, http://klichko.org/ua/about/programma/gromadyanskesuspilstvo-ta-derzhava, odczyt z 3.04.2014.

9 О. Кісь, Кого оберігає Берегиня, або Матріархат як чоловічий винахід, http://zgroup. com.ua/article.php?articleid=208, odczyt z 7.03.2008.

10 О. $\Lambda$ Сакрієр. Технології конструювання іміджу лідера політичної партії у парламентських виборчих кампаніях України, http://mydisser.com/ru/catalog/view/247/249/13093.html, odczyt z 10.04.2013. 
wizerunku Tymoszenko, oprócz wyjaśnienia bazowego archetypu, pozwoli nam ujrzeć genderowy aspekt pytania, a zarazem odwołać się do szerokiego kulturowego tła.

Polityka przez lata była męską domeną, więc asortyment archetypów, które mogą wykorzystywać kobiety-politycy, jest ograniczony w porównaniu do męskich (na przykład, jest pozytywny męski archetyp Mądrego Starca, lecz nie ma Mądrej Starej: to wiedźma). Popularne archetypy to archetypy Matki, Panny, Bogini, Kapłanki, Królowej, lecz trzeba wziąć pod uwagę, że w niektórych społeczeństwach pozytywnie będą odbierane tylko niektóre z nich.

W ukraińskim społeczeństwie, z jego tendencją feminokracji, kultem kobiety-matki, matki-ziemi, matki-natury (mężczyzna występuje jako bierny obiekt) $\mathrm{i}$ „domowym matriarchatem” 11 , w zasadzie wszystkie pozytywne archetypy są akceptowane. Głównymi archetypami Tymoszenko w ciągu ostatnich dziesięciu lat jej politycznej kariery były archetypy: Bogini i Panny w jego dwóch hipostazach: Panny-wojownika i Panny-ofiary (Panny, którą spotkało nieszczęście).

Bogini jest bardziej skomplikowanym archetypem niż Panna. To może być bogini - nadprzyrodzona istota, a może element folkloru, na przykład, „Rusałka” albo „Beregynia”. Bogini ma siłę, której nie posiadają śmiertelnicy, i inne cechy, które ją wyróżniają spośród zwykłych ludzi.

Jeśli analizujemy wizerunek jako stereotyp, to w jego strukturze, tak samo jak w strukturze stereotypu, można wyróżnić poziomy: zewnętrzny i wewnętrzny. Zewnętrzny dzieli się się na centrum i peryferię. W centrum, jak zaznacza Dmitrij Olshanskij ${ }^{12}$, występuje kilka najbardziej zauważalnych, barwnych cech, będących psychologicznymi bodźcami.

W wizerunku J. Tymoszenko jedną z głównych, a być może, nawet główną cechą jest jej fryzura. Pod koniec lat dziewięćdziesiątych XX w., kiedy stała się zauważalną postacią na ukraińskim politycznym Olimpie, w jej obrazie dominowały cechy Rusałki - odzież w jasnych kolorach, stały uśmiech na twarzy, naturalne długie rozpuszczone włosy. Podczas przedwyborczej kampanii w 2002 zmienia się nie do poznania przy pomocy sztucznego warkocza. Tymoszenko przybiera tradycyjną fryzurą postawę zamężnej kobiety co razem z surowymi ciemnymi zamkniętymi kostiumami, w okamgnieniu przekształca ją w Beregyne - rezolutną i surową, lecz jednocześnie mądrą, doświadczoną, troskliwą i sprawiedliwą „Matriarche”13. Oprócz wspominanych przez O. Kiś kulturalno-historycznych

11 С. Аенисюк, Гендерні аспекти формування іміджу політичного лідера, httр://www. politik.org.ua/vid/magcontent.php3?m=1\&n=69\&c=1596, odczyt z 10.04.2013.

12 А.В. ОАьшанский, Основы политической психологи, Sankt Petersburg 2002, s. 90.

13 O. Kicь, op. cit. 
skojarzeń, warkocz i długie włosy mają głębsze symboliczne znaczenie. Prawie u wszystkich narodów istniała archaiczna wiara w magiczną siłę włosów i paznokci, o czym świadczą przykłady: od biblijnej historii Samsona i Dalili do rytuałów współczesnej Polinezji i ludów Gwinei. Mitologiczna świadomość nadaje włosom magicznej mocy: wiadomo, że średniowieczni inkwizytorzy wierzyli, że czary wiedźm kryją się w ich włosach, a szamanom plemion tlinkitu zabraniano rozczesywania włosów: „U wielu ludów podstrzyganie włosów było procedurą delikatną i skomplikowaną. Ludziom wydawało się, że pomiędzy nimi i każdą częścią ciała istnieje pośredni związek, który nie znika nawet po zlikwidowaniu fizycznego kontaktu. Szeroko rozpowszechniła się wiara w to, że obcięte paznokcie i włosy człowieka, które trafiły w ręce wrogów, mogą doprowadzić do choroby i śmierci. [...] Często długie włosy uważano za znak charyzmatycznej świętości i zdrowego ducha. [...] Innym razem długie włosy były znakiem królewskiej władzy lub niezależności, jak u Galów i innych celtyckich ludów" ${ }^{\prime 14}$. W związku z powyższym warkocz - codzienna fryzura J. Tymoszenko w latach 2004-2010 - ma podwójne symboliczne znaczenie: świadome - narodowe, kulturalno-historyczne, i podświadome - mitologiczno-archaiczne.

Jeszcze większe znaczenie wizerunkowe miało użycie zaimka „Ona” na serii popularnych bilbordów. Na czysto białym tle można było latem 2009 r. przeczytać: „Oni przeszkadzają. Ona - pracuje”, „Oni blokują. Ona - pracuje”, „Oni obiecują. Ona - pracuje”. Zaimek „ona” utożsamiał Tymoszenko. Kilka miesięcy później Tymoszenko zaproponowała takie wyjaśnienie: „Ona - to Ukraina”.

Badacze potraktowali taki sposób wyjaśniania jako użycie manipulacyjnych zabiegów personalizowania i utożsamienia. „Ona pracuje” - to świetna formuła dla kandydata do władzy. W wyborczej kampanii z 2010 przedstawiono nowy kreatywny obraz Tymoszenko: ona - to Ukraina, która pracuje i która zwycięży. Takiej „zuchwałej zamiany pojęć trudno było wymyślić, bowiem jakież pretensje do Ukrainy mogą mieć wyborcy, Ukrainy, która rzeczywiście pracuje, ponieważ żywa jeszcze! Jakież mogą mieć pretensje wyborcy do siebie? Zamiana pojęć 'ona - to Ukraina' rozbraja" ${ }^{\prime 5}$.

Zabieg ten, nie był jednak udany, ponieważ wyszedł poza granice archetypu, który leżał u podstaw wizerunku Tymoszenko. Utożsamienie państwa i lidera jest częścią składową archetypu Królowej, a nie „Beregyni”. Jednocześnie samo użycie zaimka - do „deszyfrowania” - idealnie wpisuje się w mitologiczny model.

14 М.Б. МеАникова, Трепаначии в древнем мире и культ головы, Алетейя 2004, s. 138-140.

15 О. Ароздов, Вона - технологія, http://www.odnako.org/blogs/vona-tehnologiya/, odczyt z 19.11.2009. 
Rzymianie zamiast imion bogów często używali epitetów, zamiast Bachus mówili - Liber (wolny). Imię jednego z najbardziej tajemniczych bóstw rzymskiego panteonu - Dobrej Bogini - pozostało nieznanym, wymawianie go było zabronione ${ }^{16}$. Odpowiednio, bohaterka bilbordów - to anonimowe bóstwo.

Oprócz Bogini specjaliści od wizerunku Tymoszenko aktywnie sięgali do różnych wariantów archetypu Panny. W 2005 roku, po pomarańczowej rewolucji do 2010 roku dominował archetyp Panny-wojownika. Panna-wojownik - archetyp bardzo silnej kobiety, która zajmuje się typowo „męską” sprawą - wojną, z lepszymi wynikami, niż mężczyźni. Ten obraz jest rozpowszechniony w skandynawskiej mitologii (walkirie), a zwłaszcza w islandzkich sagach, gdzie dla takich bohaterek istnieje specjalna nazwa - meykongr („panna-władczyni”).

W historii najbardziej znanym wcieleniem tego archetypu była Joanna d'Arc. Tymoszenko staje się uosobieniem tego archetypu na reklamowych plakatach „Wojownik światła” i „Wszystkim wyjście z mroku”: na obu plakatach trzyma w rękach miecz. Jak zaznacza badaczka Oksana Sakrijer, obraz J. Tymoszenko w tym okresie konstruował się przez manipulacyjną technikę - „trójkąt S. Karpmana”. Występowały w nim trzy główne role - prześladowcy, ofiary i wybawcy. Mechanizm ten w wizerunku J. Tymoszenko realizowano następująco: w roli Prześladowcy występował prezydent W. Juszczenko i jego otoczenie, bowiem zdradzili „ideały majdanu”; Ofiara - naród i jego nadzieje na polepszanie życia po pomarańczowej rewolucji; Wybawca - J. Tymoszenko, która broni interesów narodu ${ }^{17}$.

W więzieniu pierwszoplanowym staje sie inny archetyp - Panna-ofiara. To archetyp obrazu bohaterki artystycznego utworu, młodej i atrakcyjnej dziewczyny nad którą znęca się zbrodniarz, i która czeka na wybawcę. Możliwość użycia tego archetypu jest uwarunkowana zewnętrznymi cechami Tymoszenko.

Użycie archetypu Ofiary dla polityka jest nietypowym zjawiskiem i wymaga od specjalistów od wizerunku dużego mistrzostwa chociażby dlatego, że ofiara to przedmiot, a polityk musi być podmiotem. Wyjście z tej sprzeczności jest możliwe na drodze przenoszenia ofiary na sakralny poziom, przekształcenie jej w świętą ofiarę, co znów odsyła nas do archetypu Bogini. Archetyp Bóstwa odnoszący się do Ofiary, jest obecny w wielu mitologiach. Należy wspomnieć charakterystyczny dla chrześcijaństwa obraz wielkiej Ofiary - Jezusa Chrystusa.

Ostatnie skojarzenie, może wydać się niestosownym i nawet bluźnierczym, a jednak obecnym w świadomości zwolenników Tymoszenko, o czym świadczy, w szczególności, wiersz znanego poety Dmytra Pawłyczko „Sąd”, wydrukowany

16 J. Frazer, The Golden Bough: A Study in Magic and Religion, New York 2000, s. 334-347.

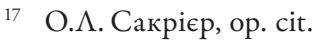


w gazecie Literaturna Ukraina w 2011 roku, gdzie porównanie i metafory wprost odsyłają czytelnika do obrazu Chrystusa: „A Prezydent swoje niewinne ręce, Czyste, myje, jak gdyby Piłat”; „Będę czekać na zjawisko zbawienne, Będę stać na śmiertelnej drodze, Dopóki Julia nie przejdzie obok mnie, Na wolę w tarninowym wieńcu" ${ }^{\prime 18}$.

$\mathrm{Na}$ Euromajdanie, po uwolnieniu z więzienia, Tymoszenko na wózku inwalidzkim nadal pretenduje do archetypu ofiary, lecz to zjawisko jest tymczasowe. Sądząc po zmianie fryzury, ma miejsce poszukiwanie nowego obrazu, w którym, najprawdopodobniej, znajdzie się miejsce dla starych archetypów.

\section{Wnioski}

Wszyscy politycy, których wizerunek został poddany analizie, wykorzystywali podstawy archetypu Bohatera i Wojownika w różnych wariantach: Bohatera-wojownika, Kulturowego Bohatera, Panny-wojownika łącząc je z innymi archetypami, w szczególności, Demiurga i Bogini. W celu zakorzenienia w zbiorowości społecznej wybranych archetypów, korzystano z wizualnych oraz werbalnych składników wizerunku, a także materiałów politycznej agitacji i propagandy. Analiza mitologicznego składnika wizerunku uwidacznia mocne i słabe strony tej manipulacyjnej techniki.

Do mocnych stron, niewątpliwie, należy zdolność tworzenia wizerunku polityka, który jest akceptowany przez społeczeństwo bez względu na wiek, płeć, wykształcenie itp. Jeśli wyborcy widzą przed sobą „prawdziwych” Boginię, Bohatera i Wojownika, będą interpretowali każdy ich uczynek, słowo i element wizerunku jako potwierdzenie mitu.

Ponieważ każdy archetyp zawiera znany zestaw cech wyglądu, praca specjalistów od wizerunku nad kształtowaniem zewnętrznej jego strony staje się łatwiejsza. Wystarczy kilka elementów, które wprost odsyłają do archetypu: warkocz, haftowana koszula, odzież w militarystycznym stylu, a resztę „dorysuje” wyobraźnia widowni. Te cechy pozwalają na wyodrębnienie politycznego lidera spośród innych uczestników politycznego procesu, czynią go uznawanym i w końcu przekształcają się w swoiste „logo”.

Apelowanie do archaicznych warstw masowej świadomości powoduje odbieranie polityka na płaszczyźnie emocjonalnej: zamiast analizowania jego politycz-

18 А. Павличко, Cуд, http://blogs.pravda.com.ua/authors/medvedev/4e8db264d9754/view_ print/, odczyt z 6.10 .2011 . 
nego programu, porównywania realnych osiągnięć i przedwyborczych obietnic, przyglądania się jego ekipie, elektorat zaczyna postrzegać polityka przez pryzmat emocji, które wywołuje wykorzystany do budowy wizerunku archetyp. Charakter i ukierunkowanie tych emocji zależą od właściwości archetypu ale w każdym przypadku wywołują iluzję (przede wszystkim nadzwyczajnych możliwości politycznego lidera).

Sięganie do archetypu jako podłoża stanowić może potężną broń, ale jak każda broń, ukrywa w sobie niebezpieczeństwo. Główny problem polega na tym, że, będąc niezwykle skutecznym w sytuacjach emocjonalnego uniesienia, archetypy nie działają, kiedy ocena polityka i stosunek do niego przechodzi do sfery racjonalnego myślenia i racjonalnej oceny. Wizerunek, który bazuje na archetypach, w większości wypadków wymaga wyjątkowej wiary: elektorat albo wierzy (Tymoszenko), albo nie wierzy (Jaceniuk) w to, że stoi przed nim Bogini albo Bohater. Jeżeli polityczny lider w świadomości społecznej nie kojarzy się z obrazem mitologicznej postaci i ogół nie wierzy w prezentowany przez niego wizerunek, ciągnie to za sobą rozczarowanie, tzn. jeśli elektorat nie uwierzył, że przed nim stoi Bohater, to nie uwierzy i w jego kwalifikacje, zdolności organizatorskie, chociaż nie mają one nic wspólnego ze światem archetypów.

Ponieważ w krytycznych sytuacjach racjonalny osąd sytuacji jest blokowany, to dołączenie mitologicznych modeli jest charakterystyczną oznaką społecznego kryzysu, niestabilności. Społeczeństwo potrzebuje bohaterów w czasie wojen i rewolucji, więc jedną z oznak zakończenia przejścia od autorytarnego do demokratycznego społeczeństwa będzie przemiana archetypicznego podłoża czołowych polityków. 